\title{
BOTTOM-UP MODEL ANALYSIS OF COMMUNITY INVOLVEMENT IN THE SISTER CITY COOPERATION FOR FLOOD MITIGATION IN EAST KALIMANTAN
}

\author{
M. Najeri Al Syahrin, Mahyuni, Apriansyah, Andi Tenri Sompa, Jamaluddin, Asmu'i, \\ Setia Budhi, Dzul Rachman, Hardi Alunaza ${ }^{1}$ \\ Universitas Lambung Mangkurat, Universitas Muhammadiyah Kalimantan Timur, \\ Universitas Tanjung Pura
}

\begin{abstract}
:
Sister city cooperation has emphasised the role of the state and local government However, the role of the community is also essential.although has been relegated to a second place. This article aims to apply the model of community involvement in the sister city's flood prevention cooperation plan in Samarinda city, East of Kalimantan, emphasizing the active citizen participation (citizen diplomacy). The analysis of community involvement with the bottom-up model in sister city cooperation starts with the identification of flooding problems in three samples of Saramarinda urban villages presenting its performance and outcomes. This approach is new in solving the Samarinda flood problem, which so far has tended to be centralized and ineffective.
\end{abstract}

Keywords: Sister City Cooperation, Flood Problems, Community Involvement, Bottom-up Model.

Título en Castellano: Análisis del Modelo Ascendente de la Participación Ciudadana en la Cooperación de entre Ciudades Hermanas para la Mitigación de las Inundaciones en el Este de Kalimantan

\section{Resumen:}

La cooperación entre ciudades hermanas ha hecho hincapié en el papel del Estado y del gobierno local y, si bien el papel de la comunidad también es esencial, esta ha quedado relegada en los estudios. Este artículo intenta analizar el modelo de participación comunitaria en el programa cooperativo de prevención de inundaciones entre ciudades hermanas de Samarinda city, en el Este de Kalimantan, enfatizando el papel de una participación ciudadana activa (diplomacia ciudadana). El análisis de la participación comunitaria con el modelo de cooperación ascendente entre ciudades hermanas es un modelo de cooperación que empezó con la identificación de los problemas de inundación en una muestra de tres pueblos urbanos de Samarinda, presentando su eficiencia y los resultados. Este enfoque es nuevo, en un intento de solucionar el problema de las inundaciones en Samarinda, que hasta ahora ha sido bastante centralizado e ineficaz.

Palabras Clave: Cooperación entre Ciudades Hermanas, Problemas de Inundación, Participación Ciudadana, Modelo Ascendente.

Copyright (C) UNISCI, 2019.

Las opiniones expresadas en estos artículos son propias de sus autores, y no reflejan necesariamente la opinión de UNISCI. The views expressed in these articles are those of the authors, and do not necessarily reflect the views of UNISCI.

\footnotetext{
${ }^{1}$ M. Najeri Al Syahrin is Lecture at Universitas Lambung Mangkurat, E-mail: <najeri.syahrin@ulm.ac.id>. Mahyuni is Associate Professor at Universitas Lambung Mangkurat, E-mail: <mahyuni.fisip@ulm.ac.id>. Apriansyah is a Ph.D. Candidate at Universitas Diponegoro and Lecture in Universitas Lambung Mangkurat, Email: <apriansyah.fisip@ulm.ac.id>. Andi Tenri Sompa is Lecture at Universitas Lambung Mangkurat, E-mail: <tenri@ulm.ac.id>. Jamaluddin is Lecture at Universitas Lambung Mangkurat, E-mail: Jamal.fisip@ulm.ac.id. Asmu'i is Professor o Public Administration at Universitas Lambung Mangkurat, E-mail: <asmui.publikfisip@ulm.ac.id>. Setia Budhi is Lecture at Universitas Lambung Mangkurat, E-mail: <setia.budhifisip@ulm.ac.id>. Dzul Rachman is Lecture at Universitas Muhammadiyah Kalimantan Timur, Email: <dzulrachman@umkt.ac.id>. Hardi Alunaza is Lecture at Universitas Tanjung Pura, E-mail: hardi.asd@fisip.untan.ac.id.
}

DOI: http://dx.doi.org/10.31439/UNISCI-88 


\section{Introduction}

Globalisation and the information revolution have influenced the distribution of power within the nation-state. This significant change has caused the centralisation of social problems managed by the central government to decrease as the increasing need to solve social issues independently has been for regional governments. Consideration of order and better governance has made local governments try to be active in government relations both at home and abroad. ${ }^{2}$ Devolution of power from the district level government to the sub-district government can effectively increase economic and social development and improve integration of urban and rural areas. Local governments can also act as initiators and promoters of reform. ${ }^{3}$

Global changes due to globalisation caused a shift in the implementation of state and government relations. Advances in communication technology have also encouraged interdependence not only for the state but also groups within the state, including regional governments. ${ }^{4}$ This phenomenon makes local governments interested to establish cooperation with local governments in other countries to benefit the region. The most common form of bilateral cooperation is the sister city partnership model. Sister city is a form of collaboration that involves cities in one country and cities in other countries to increase the sense of brotherhood between cities and benefit the two cities. ${ }^{5}$

It estimated that $70 \%$ of cities in the world currently participate in various forms of partnership and cooperation programs between cities. Cities and regional governments have stepped into the arena of international development cooperation around the world. Cities work together to improve local governance and improve social development and its various problems. This effort, viewed from a historical perspective, has been practiced to serve a variety of community objectives, including to build post-war peace and increase solidarity with shared problems. ${ }^{6}$ Sister city cooperation seen as a promising mechanism for creating and developing capacity in the regions and contributing to improving living conditions in urban communities. ${ }^{7}$

Sister city cooperation exists to strive for regional development not only in the area of economic profit but also able to solve urban problems. ${ }^{8}$ Given the increasing 'urban' recognition in development thinking, it appears that the presence of cities and local governments in international cooperation will be increasingly needed. It manifested by the growing number of cities in international activities and uniting cities to work on various development problems. ${ }^{9}$

\footnotetext{
${ }^{2}$ Shah, Anwar et al: "Empowering States and Provinces or Unshackling Local Governments: Does It Matter for Peace, Order, Good Government, and Growth", The Pakistan Development Review, Papers and Proceedings Parts I and II The 26th Annual General Meeting and Conference of the Pakistan Society of Development Economists Islamabad, Vol. 49, no 4 (December 2010), pp. 335-336.

${ }^{3} \mathrm{Yu}$, Jianxing et al: "Rediscovering Intergovernmental Relations at the Local Level: The Devolution to Township Governments in Zhejiang Province", China Review, Vol. 16, n 2 (June 2016), pp. 18-19.

${ }^{4}$ Buckley, Patrick Henry et al: "The Role of Sister Cities' Staff Exchanges in Developing "Learning Cities": Exploring Necessary and Sufficient Conditions in Social Capital Development Utilizing Proportional Odds Modeling", Environment Res Public Health, Vol. 12, nº 12 (June 2015), pp. 1-13.

${ }^{5}$ Ogawa, Asuka: "Sister City As A Preservation Strategy", Thesis, Graduate School of Architecture, Planning, and Preservation, Columbia University, (2012), pp. 20-22 at

https://pdfs.semanticscholar.org/ce1b/b7db56d38a516a49b65864a8c69c8e36274c.pdf

${ }^{6}$ Bontenbal, Marike: 'Dutch Policy on City-to-City Cooperation for Improved Local Governance in South Africa', paper presented at the 5th International Winelands Conference "Public Management and Development: Illusion, Delusion, (April 2015), University of Stellenbosch, South Africa, pp. 7-19.

${ }^{7}$ Ibid., pp. 7-19.

${ }^{8}$ Mukti, Takdir Ali (2013): Paradiplomasi: Cooperation by Regional Government In Indonesia (Paradiplomasi: Kerja Sama Oleh Pemda Di Indonesia), Yogyakarta, The Phinisi Press, pp. 2-5.

${ }^{9}$ Bontenbal, Marike: "The Role of European Local Governments in Development Cooperation: Examples from the Netherlands and Germany", in Hoebink Paul (ed.) (2010) European Development Cooperation: In Between the Local and the Global, Amsterdam, Amsterdam University Press, p. 287.
} 
The formation of sister city cooperation also shows that each regional government cannot always rely on its domestic potential to meet its needs, but can be fulfilled by other countries through a cooperative scheme. ${ }^{10}$ Local government, in the Indonesian bureaucratic system, occupies a strategic position in society. The relationship between the local government and the central government has become the main area of inquiry and the key to understanding the transformation and reform that is happening in Indonesia. ${ }^{11}$

Samarinda as the capital of East Kalimantan, Indonesia still has a significant problem today, flooding. Flood conditions are bothersome activities of the community ${ }^{12}$. Various efforts have been made, such as maintenance of city drainage channels, improvement of rivers that cross the city, multiple studies related to city flood control, construction of flood control facilities and several rules have been issued for flood control, but these efforts are still not optimal in overcoming the problem of flooding. ${ }^{13}$

Therefore, a new framework for integrated flood management is been developed through sister city cooperation. In sister city cooperation, flood control will involve various experts on flood problems in the international world, who have experienced in dealing with floods in their states with active citizen engagement. Also, sister city cooperation allows technology transfer in handling flood problems, so it is expected that through this cooperation mechanism, the flood problem in Samarinda could be resolved.

Based on the description, it appears that there has been a shift, strengthening the role of local governments in the context of foreign relations. Related to this, the purpose of this study is to find out how the model of community involvement in the framework of practical sister city cooperation can be implemented in handling floods in the city of Samarinda. With sister city cooperation, it is expected that the strengths of each city that carries out the cooperation could achieve synergies to deal with the threat of flooding, something that is very complicated if handled individually. Collaborating parties can make progress through the mechanism of transfer of knowledge, information, and technology. One city can learn from other cities so that in the end it will advance the welfare of the people.

This research was developed using qualitative research methods. This method uses a combination of studies and interviews to understand how the model of sister city cooperation is applied in the flood mitigations. Semi-structured interviews with four (4) interviewees were conducted. Respondents were the executors and facilitators of the sister city policy, and three criteria were used to identify the proper respondents: (1) Representatives of the government who have a high knowledge of the flood prevention cooperation, (2) Involved in the direct flood prevention policy in the community, and (3) reside in the city of Samarinda. Observations and interviews were conducted in Samarinda, East Kalimantan, Indonesia for 2017-2018 and continued to collect data for 2018-2019. The four interviewed are labelled Q1, Q2, Q3, Q4. The informant is a representative of the city government of Samarinda (Q1). The leadership of the village of Temindung (Q2), representatives of Kelurahan Sempaja Timur (Q3), and the leaders

\footnotetext{
${ }^{10}$ Fitriah, Hendrini Renola and Rani, Faisyal: "Implementation of Sister City Collaboration: Sister City BandungBraunschweig Case Study in 2000 - 2013 (Implementasi Kerjasama Sister City: Studi Kasus Sister City BandungBraunschweig Tahun 2000 - 2013)", Transnasional, Vol. 1, nº. 5, (July 2013), pp. 932-940.

${ }^{11}$ Zhou, Xueguang: "The Institutional Logic of Collusion among Local Governments in China", Modern China, Vol. 36, no. 1, (January 2010), p. 48.

${ }^{12}$ Jovita, Hazel D., Nurmandi, Achmad., Mutiarin, Dyah and Purnomo, Eko P.: "Why does network governance fail in managing post-disaster conditions in the Philippines?" Jàmbá: Journal of Disaster Risk Studies, Vol.10, nº 1 (2018).

${ }^{13}$ Rafiq: "Study of Disaster Programs in Flood Disaster Management in Samarinda City at the Regional Disaster Management Agency (BPBD) of East Kalimantan Province" (Studi Tentang Program Kebencanaan Dalam Penanggulangan Bencana Banjir di Kota Samarinda Pada Badan Penanggulangan Bencana Daerah (BPBD) Provinsi Kalimantan Timur)", Administrative Reform Fisip Unmul, Vol. 2, no 3 (2014), pp. 1548-1560.
} 
of Gunung Lingai (Q4). The village election carried out because it is the main area affected by the extreme flood in Samarinda, East Kalimantan. Research restrictions are only conducted in the city of Samarinda as the provincial capital of East Kalimantan so that analysis of the community involvement model can be obtained in detail

\section{Citizen Diplomacy and the Role of Transnational Actors in a Broader Dimension}

In providing an analysis of the description of the active role of the community in sister city cooperation, the authors use the concept of citizen diplomacy. Citizen diplomacy or other terminology is a bottom-up diplomacy, a platform of contemporary foreign policy carried out by the community and city government through cultural exchanges and the exchange of science and technology. ${ }^{14}$ There are some significant differences between the behaviour of the central government (state) and local government (city) in foreign policy. A country's foreign policy tends to be implemented taking into account long-term national interests and the country's strategic interests. In the foreign policy of the regional government (city)these interests are driven by the short-term needs of the area's problems.

The Regional potential which is sometimes not always in line with regional requirements has led to initiatives and desires for local or city governments to conduct citizen diplomacy at the global level, as an effort to fulfil regional interests. In addition to fulfilling regional potential, the similarity of the problems faced is one of the main reasons for the formation of sister city cooperation between city governments. ${ }^{15}$

The concept of the relationship between the state and society has risen at the same time as the emergence of the era of globalisation, which made states realise that they were no longer the primary solution in achieving national goals or interests that could also be achieved through public diplomacy.

Developing mutual international cooperation is one of the more effective ways of achieving the goals and interests of the country. ${ }^{16}$ It means that the role of the state can be biased by the smallest actors of the sub-state, namely the community or the city government.

The significant role of sub-state actors is an essential factor that is now changing interactions between countries. The increased relations between communities, organisations, and groups have led to the ease of communication of transnational relations and the resolution of sub-state problems on a global scale. This interaction will eventually has produced many effects and is depicted in Figure 1.

\footnotetext{
${ }^{14}$ Baritono, Rafaella: "Eleanor Roosevelt at the United Nations: "Diplomacy from Below" and the Search for a New Transatlantic Dialogue”, European Journal of American studies, Vol. 1, nº. 12, (Spring 2017), p. 15.

15 Pramono, Sugiarto: "Driving Factors of Cooperation in the Sister Province of Central Java-Queensland (Australia) 1991-2009 (Faktor Pendorong Melakukan Kerjasama Sister Province Jawa Tengah-Queensland (Australia) 1991-2009)", Eksplanasi, Vol. 8, nº 4 (October 2009), pp. 109-119.

${ }^{16}$ Nye, Joseph and Keohane, Robert: "Transnational Relations and World Politics: An Introduction", International Organization, Vol. 25, nº. 3 (Summer 1971), pp. 334-335.
} 
Figure 1. Interaction of international actors

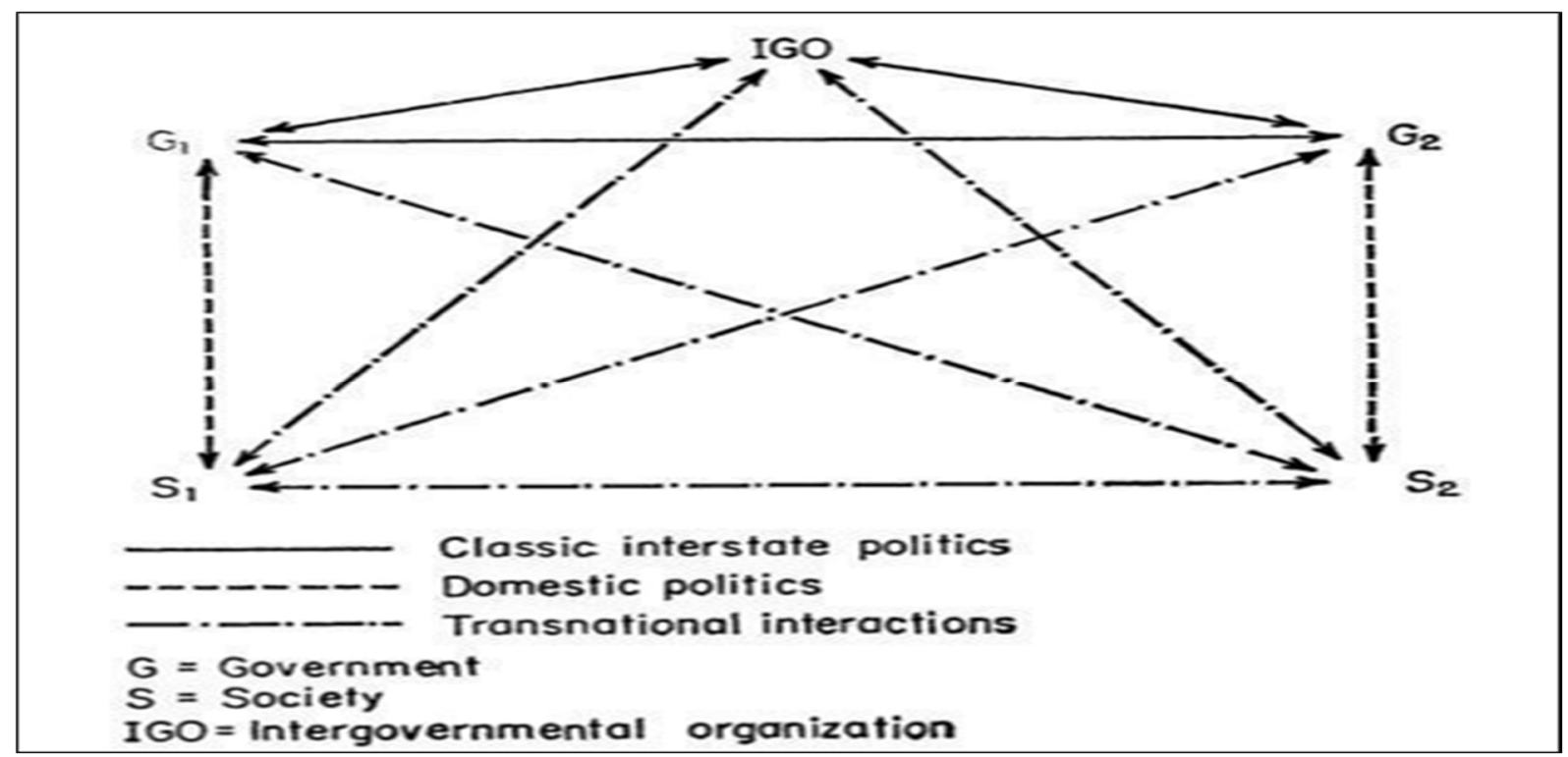

Source: Nye and Keohane (2003)

In the figure, Nye and Keohane explain the role of transnational actors in a broader dimension. They identified an expansion of actors from roles that had only been carried out by the government now could also be carried out by the city government through the role of the people therein. Transnational relationships also take the form of individual or community relations that have important consequences in the problem-solving process. ${ }^{17}$ In understanding the resolution of the flood problem in Samarinda, the interaction of transnational actors is carried out with the Samarinda City Government or the government (G) and the Samarinda community or society (S) on the other side. In this pattern, it explained that the community group or society (S) exerts influence and pressure on the government or government (G) in global interactions and cooperation. With the support and pressure from the community or society (S), local governments strive for mutual transnational relations directly with the transfer of power from the central (state) government to regional (city) governments. It can be concluded that the internationalisation of the Samarinda flooding problem can create interaction relations between state and non-state actors that cross-national territorial boundaries. The role of the state no longer dominates the patterns of interaction of international cooperation that are developing now, but the smallest state actors such as the people (citizen diplomacy) and city government. ${ }^{18}$

The cooperation model that we will examine in this study consists of two process. The first is the sister city top-down cooperation model, which is an agreement between the regional heads in each city. In this model of cooperation, the local government has prepared several experts to conduct studies on various city problems identified in the twinning of cities. While the second model is known as the sister city bottom-up cooperation model. In this model, cooperation formed through the efforts of community groups, including academics, professional groups, and NGOs that have the initiative to form sister city cooperation. This community group initiative was then officially proposed to the government for consideration. ${ }^{19}$

\footnotetext{
${ }^{17}$ Ibid., pp. 334-335.

${ }^{18}$ Odoh, Nwogbaga and David: "Reflection on the Theory and Practice of Citizen Diplomacy in the Conduct of Nigeria's Foreign Policy”, IOSR Journal Of Humanities and Social Science, Vol. 19, n 10 (October 2014), pp. 210 .

${ }^{19}$ Sunarko, Bagus Sigit and Yuniati, Sri: "Sister City Collaboration: An Effort to Improve the Tourism Industry in Banyuwangi (Kerjasama Sister City: Sebuah Upaya Untuk Meningkatkan Industri Pariwisata Di Banyuwangi)”,
} 
The bottom-up model is the model approach that will be chosen as the sister city cooperation model in the development of this research. The main reason for selecting this model is the Samarinda flood problem, a problem where people suffer many important losses due to flooding. Logically, this should require the role of the community in the resolution process. Besides, the problem of flooding is a problem due to the social lifestyle of people who do not pay attention to the environment. Therefore, in line with this statement, the creation of cooperation in flood management will be effective to carry out if community participation is high. The series of policy processes in this model begins with community groups, including groups of academics, businesses, and NGOs who are simultaneously moving together to conduct studies on sister city cooperation. The study was then submitted to the city government as a material consideration in making government policies, especially in dealing with flooding problems. In the process, the stages must be carried out, evaluatively, and accommodate the aspirations of the community. Therefore, it was hoped that the sister city bottom-up strategy model of cooperation is one of the good models of cooperation to be developed. ${ }^{20}$

\section{Discussion and Results}

The sister city or twin city cooperation model is a model of cooperation between one city and another city that is transnational based on similarities such as disasters, geographical, economic, social structure, cultural and other matters that have in common that the two cities have in common. This study plans to analyse a model of community involvement in sister city cooperation in Samarinda City, East Kalimantan Province. This research also involved people in the flood-affected areas in participating in conducting the model sister city cooperation.

The research implementation process began by interrogating the Samarinda city government at Samarinda City Hall. The Samarinda city government conveyed through the specialised staff of the collaboration section of Andi Tenri Sumpala (Q1), who explained that in the city of Samarinda itself, there was no process of implementing sister city cooperation. It is because there are several obstacles experienced by the Samarinda city government itself. The constraints experienced by the Samarinda city government are that the first issue of funding for sister city cooperation by the Samarinda city government has not yet realised. Second, it has not been integrated between unit one with other units so that excellent communication has not established for the implementation of the sister city cooperation.

The respondent Q1 also explained these two obstacles are the problems why the Samarinda city government has not run the sister city cooperation model to date. Information obtained from the Samarinda city government for the implementation of sister city cooperation to overcome the flood problem has discussed, namely the plan for flood management with Diponegoro University (Undip) in Semarang, where Undip also offers a flood management plan and a manifestation of Samarinda Mayor's vision and mission regarding flood management.

The sister city cooperation research in Samarinda City has also been carried out by contacting several related parties such as Samarinda city government, urban village (kelurahan), and the community as actors in the implementation of sister city, and conducting field surveys related to regions that will be used as sister city cooperation implementation, namely in Temindung Permai urban village, East village of Sempaja, and Gunung Lingai urban village. These three urban villages are the research sites of the sister city model collaboration in Samarinda City with the active involvement of the community. The first is the Temindung Permai urban village. Temindung Permai is one of the urban villages in Sungai Pinang Subdistrict, with an area of around +/- 130.56 Ha, Temindung Permai has a population of

Repository, Fakultas Ilmu Sosial dan Politik, Universitas Jember, 2016, pp. 1-12, at http://repository.unej.ac.id/bitstream/handle/123456789/79341/221-234_1.pdf?sequence=2

${ }^{20}$ Tachjan (2006): Public Policy Implementation (Implementasi Kebijakan Publik). Bandung, AIPI, pp. 10-17. 
18,184 consisting of 9,441 men and 8,743 women with the number of family heads of 4,852 households spread in 39 neighbourhood units. ${ }^{21}$ The total area of the Temindung Permai Village is 130.5 hectares, which was affected by flooding around 90 hectares including 39 Neighbourhoods in it, although some were severely affected and not. Another obstacle faced after the flood is the piles of garbage left behind, especially plastic waste, which is one of the primary sources of flooding.

The Head of Temindung urban village, Dili Satria Handoko (Q2) responded well to the sister city cooperation framework with the active involvement of the community in Samarinda's flood mitigation efforts. Analysis of community involvement in sister city cooperation shows that the population has played an active role in flood mitigation, becase of the local wisdom of the community in managing the river and its ecosystem. The community must also be engaged in monitoring the area around the river that can be jointly maintained. The stream of concern for the flooding in the Temindung area is the Karang Mumus river, where the river becomes the Mahakam River in Samarinda. Therefore, education needs to be done to the community for the creation of local wisdom in protecting this river ecosystem. Besides, the government also built a dam to manage water that it is well maintained, namely in the Benda-Benda. This dam is a critical infrastructure of the city that is functioning as a water source and water reservoir in the town of Samarinda.

An essential point of handling floods in addition to the development of urban infrastructure is also the concern in the community for the river ecosystem. With the concept of a waterfront city, it will be explored more deeply to become a part of river tourism or marine tourism vessels that will be carried out in Samarinda. The second point is controlling the buildings along the river banks throughout the Samarinda region. It is done more precisely to sterilise or maintain the river ecosystem so that it remains natural without any community settlement around the river banks. Q2 also stated the reality faced by the government at the moment is that the activity of protecting the river ecosystem and handling floods in Samarinda city has not carried out correctly, and there are still many people who are not fully aware of the need to protect the river ecosystem, and preserve local wisdom, namely caring for the river's survival as its function. Temindung urban village leaders (Q2) also provides education to the community regarding flood management and protecting the river ecosystem with a new method, namely through the GERCEP online media application, so that the community can have 24 hours access to tips and procedures as well as monitoring in handling floods and conducting disaster response simulations. The application of online media can be a new educational tool for people in the Temindung area and a proof of the effectiveness of the engagement activity of the community, being an example the creation of regular garbage collection sites that have been carried out in the neighbourhood (RT 2) Temindung.

Urban village (Kelurahan) also appealed to the community to be aware of protecting the river ecosystem and trying to educate the public in responding to floods and minimise flooding in the area. This phenomenon is confirmed by respondent Q2 that the urban village also uses the Temindung pro website as an official channel of online urban village information that can be accessed directly and quickly by residents as a new method of educating and making residents aware of protecting the river and handling flood disasters. The other urban village that became the study sample was East Sempaja. East Sempaja is one of the urban villages in the North Samarinda district, Samarinda City, East Kalimantan Province, Indonesia. East Sempaja Village is one of the villages that formed in 2014, by following with Samarinda City Regional Regulation No. 6 of 2014 concerning the Expansion of urban village within Samarinda City

\footnotetext{
${ }^{21}$ Samarinda City Government: "History of Temindung Permai Village (Sejarah Kelurahan Temindung Permai), Samarinda City Government Online Publications, (January 2017), at https://kel-temindung-permai.samarindakota.go.id/pages/sejarah-UMCS.
} 
Region. ${ }^{22}$ East Sempaja Urban Village divided into 3 (three) Urban Districts. East Sempaja Sub-district also has 50 (fifty) neighbourhood units (RT/Rukun Tetangga) with a population of \pm 23 thousand inhabitants. ${ }^{23}$

Research on sister city cooperation in flood mitigation was carried out in this urban village because East Sempaja is the largest flood center area of Samarinda, due to the location of the area which is a lowland, natural swamp that holds runoff from now becoming a settlement. Based on the results of interviews related to the analysis of community involvement in handling floods with the Head of the Economic Development and Environment Section of East Sempaja Village office, Sipriyani (Q3). It conveyed that the East Sempaja sub-district itself had been promoting community service as a 3-month program to deal with floods in the area, namely by cleaning clogged gutters. The community service action is also carried out once a month by the neighbourhood (RT (Rukun Tetangga) There is a total of 1 neighbourhood in the Eastern region. East Sempaja itself is an area of expansion of South Sempaja which has been running since three years ago.

Fifty-one neighbourhoods in the East Sempaja Village, around 30\% were affected by the most significant floods, namely in the area of neighbourhood 5 (RT 5), Gang Kuburan, neighbourhood 21 (RT 21) Solid Karya and neighbourhood 26 (RT 26) in the Puspita area. This condition is confirmed by respondent Q3 that the flood disaster in this area is because the East Sempaja area is swampy and is near a riverbank, and infrastructure and residential areas are too dense. These three obstacles become the pathway for flooding in the East Sempaja region.

The third urban village in this study sample is Sungai Linggai (Q4). Reports from urban village Gunung Lingai in Samarinda related to sister city research in Samarinda's flood response were responded to well. The main problem conveyed is that there must be normalisation of the river that is by carrying out cooperation which has been held routinely every week from every existing neighbourhood (RT). The next effort is to relocate the houses of residents in the river area, namely by urging people to move out of the area to prevent flooding due to the construction of housing infrastructure in the river area as stated by respondent Q4.

The respondent Q4 explained the Samarinda Public Works Office (PU) has also handled floods from the Mugirejo area to Citra Land. It has also been able to reduce the impact of flooding experienced by residents of Gunung Lingai. From the 23 neighbourhoods (RT), 60\% are still affected by floods, such as neighbourhood (RT) 18, 20, 17, 15, 14, 1, and 8 . The flood impacts experienced by this region are not categorised as severe floods but only included in the low category of 2- 3 hours have receded and are normal. ${ }^{24}$

In general, the three villages according to Q2, Q3, and Q4 have different problems and concepts of community involvement, and the differences based on community characteristics and differences in the causes of flooding problems faced by each village in Samarinda. In general, of the three urban villages, three aspects of community involvement in the Samarinda city flood prevention can be identified. In the Temindung Permai urban village, active community involvement through education on the importance of protecting the river ecosystem and the socialisation of local wisdom so that the community can overcome the problem of flooding. In the urban village of East Sempaja, the active involvement of the community manifests itself in the form of cooperation in cleaning waterways and drainage. While in the village of Gunung Lingai, active community involvement can take the type of housing

\footnotetext{
${ }^{22}$ Regional Regulation of Samarinda City, Number 6, 2014.

${ }^{23}$ Samarinda City Government: "History of East Sempaja Village (Sejarah Kelurahan Sempaja Timur). Samarinda City Government Online Publications, (January 2017), at https://kel-sempaja-timur.samarindakota.go.id/pages/sejarah-QDEUJ. ${ }^{24}$ Ibid.
} 
structuring and relocation as well as riverbank settlements. Arrangement of residential areas around the riverbanks is considered a crucial problem in handling flooding in Gunung Lingai urban village.

The third analysis of community involvement can be an essential capital in building a framework of cooperation between city partners (sister city) with the active participation of the community. Not only to increase the potential of the city of Samarinda, but sister city cooperation can also be used to solve the main problem of the city of Samarinda, which is the problem of flooding. One form of cooperation network is the sister city partnership. This collaboration is carried out with cities both at home and abroad, generally done with cities overseas. Based on the results of interviews with Q1 so far there has not been sister city cooperation done either in flood mitigation or other problems. Therefore, in this study, there will be an effort to initiate sister city cooperation, especially in the Samarinda flood control. This collaboration and partnership activity focuses on developing diplomatic, friendly relations and benefits for both parties, especially in solving city problems.

Efforts to overcome the problem of flooding that only relies on development carried out by the city government until now has proven to be ineffective in overcoming or reducing the Samarinda flooding problem. So that we need a flood control model that is integrated and comprehensive by referring to the efforts of non-structural development, especially the fabric of partnerships (cooperation) involving all stakeholders both at home and abroad. This research proposes that the government can include all parties to jointly implement a flood control system with active citizen engagement (citizen diplomacy). The active involvement of the community reflected in the active participation of the population in the framework of sister city cooperation with the bottom-up model. In this model, sister city cooperation is carried out cities between countries in handling floods by involving the community in the formulation and implementation of agreements. These activities, including floodplain management, flood-prone areas, flood forecasts and early warning, settlement relocation, spatial improvement and reforestation, watershed erosion reforestation, determination of river borders, delivery of public information and strengthening information and management garbage. ${ }^{25}$

The analysis of community involvement with the bottom-up model in the cooperation of city partners (sister city) is a model of collaboration that begins with the identification of flood problems in each area of Samarinda city and a comprehensive study of flood resolution strategies from the perspective of the community. The type of activity initiated by the City Government will encourage the community to work on implementing the policy actively. This model also views the policy process as negotiation and consensus-building that carried out collectively, involves elements of governance and relies on persuasion.

The main arguments of this model are effective performance (outcome), social virtue (local wisdom) and substantiality from the micro-region to the broader area (community to the government). Analysis of the community involvement model in this bottom-up model also tends to be trend-oriented, responsive and short-term, carrying micro-substance that is local and the primary source of its approach through the community.

The sister city bottom-up cooperation model is planning in flood mitigation where the community has a central role in giving ideas from the initial activities, to implementation and evaluation. In this case, the Samarinda city government only acts as a development facilitator. In general, the sister city bottom-up cooperation model has several advantages, including being able to have an active role in providing ideas in the development of urban planning programs.

\footnotetext{
${ }^{25}$ Gusti: "UGM Experts Give Feedback to Overcome Jakarta Floods (Pakar UGM Beri Masukan Mengatasi Banjir Jakarta), Universitas Gadjah Mada Online Publication, 23 January 2013, at https://ugm.ac.id/id/berita/4858pakar.ugm.beri.masukan.mengatasi.banjir.jakarta.
} 
Also, the public can find out in detail the implementation of flood mitigation from the beginning of the activity to the evaluation. However, this cooperation model also has some weaknesses. Namely, the role of the government is not optimal and only becomes a facilitator in the implementation of cooperation. Besides, there are often misunderstandings between the community and the government because of differences in views in many ways. In brief, the government approach in the sister city collaborative effort to overcome floods assumes that the Samarinda city government is agenda-setting for policymaking in flood management by encouraging the involvement of other actors such as urban communities to be actively involved in making cooperation in flood management. In the current era of globalization and autonomy, assistance is needed to address regional problems that are often neglected and cannot adequately be resolved. ${ }^{26}$

The keywords for the success of this collaboration are responsibility, decisions, and real action when a disaster occurs and how the evacuation is carried out. All of which is jointly borne by the municipality (municipality) and residents (residents).. ${ }^{27}$ The city government acts as a forecaster to monitor flood-prone areas and provide guidance to residents. The city government should also collaborate with volunteers and NGOs in assisting in the form of funds and energy to the community. The community also strives always to be trained in preventive efforts in critical situations of disaster to be able to provide the best response when an emergency occurs. Preparedness, resilience and active community participation are crucial in dealing with flooding problems. ${ }^{28}$

Although there are some weaknesses in this model, especially it requires a lot of time and energy in planning, but hopefully, the results can be more effective in flood management. This sister city bottom-up cooperation model is a city development plan based on participatory development.

The increased participation of regional governments in regional and global governance also shows that the potential for democracy can arise from local (community) responses. The potential for democracy that arises from local authority in global governance is rooted in the belief that we must accept the conditions of globalisation and its consequence that the reach of government crosses State boundaries. ${ }^{29}$

Samarinda City Government should try to do participatory development planning to explore the aspirations that develop in the community through deliberations at the neighborhoods, hamlet, urban village, Sub-district, and cities levels. Community participatory development planning in international cooperation is a pattern of approach that involves the active role of the community not only as an object but also as a subject of development so that the nuances developed in urban development planning and problem-solving are indeed a bottom-up approach. ${ }^{30}$ Nevertheless, the development planning and resolution of urban

\footnotetext{
${ }^{26}$ Weibleder, Stephan and Lackner, Hartmut: "Top-Down and Bottom-Up Approach for Model-Based Testing of Product Lines”, Arxiv, (August 2019), pp, 83-89., at https://arxiv.org/pdf/1303.1011.pdf.

${ }^{27}$ Pribadi, Sugeng: "Learn How Japan Fought Floods (Belajar Bagaimana Jepang Mengaatasi Banjir)", Berita Iptek, (4 April 2007), at http://www.beritaiptek.com/zberita-beritaiptek-2007-04-04-Belajar-Bagaimana-JepangMemerangi-Banjir.shtml

28 National Disaster Management Authority. "SCDF Committed to Establishing Disaster Management Cooperation (SCDF Berkomitmen Jalin Kerjasama Penanggulangan Bencana)", Badan Nasional Penanggulangan Bencana Online Article. (27 February 2017), at https://bnpb.go.id/scdf-berkomitmen-jalin-kerjasamapenanggulangan-bencana.

${ }^{29}$ Alger, Chadwick: "Searching for Democratic Potential in Emerging Global Governance: ¿What Are the Implications of Regional and Global Involvements of Local Governments?," International Journal of Peace Studies, Vol. 16, nº 2 (Winter 2011), pp 133-135.

${ }^{30}$ Petrenko, Alexander and Schlingloff, Holger: "Eighth Workshop on Model-Based Testing", Proceedings Eighth Workshop on Model-Based Testing, Rome, Italy, 2 March 2013, pp. 2-12, at https://arxiv.org/abs/1303.0379
} 
problems involving all elements and components of the community are positive steps that deserve to be observed and developed on an ongoing basis both at the level of thought discourse and at the level of its implementation during its particular community engaged in international fora. At the same time, this approach is new in solving the Samarinda flood problem, which has so far tended to be ineffective and centralized. ${ }^{31}$

The active involvement of Samarinda communities in flood mitigation in the sister city cooperation scheme is seen in decision making and participation in supervision. In the process of developing a flood-free area of Temindung district and Sempaja Timur district, the Village Head involved residents in making decisions regarding village level regulations to overcome flooding problems such as littering fines, houses must have water catchment areas, plant trees in the yard and improve drainage in the neighborhood. This shows that residents participated in the management and development of the flood-free regions. Involvement in supervision, that is, residents, participate in supervising all infrastructure development related to flooding with active monitoring mechanisms through neigbourhood, urban village and district. Besides, residents are also involved in the emergency disaster response system in a flood alert situation with GERCEP online media application.

The idea of sister city cooperation was original to improve people to people diplomacy. Still, along with the times, the goal shifted to create a more concrete collaboration that is mutually beneficial to both parties by not forgetting the participation of the people in it. On the Samarinda Government itself, the people involved in sister city have represented some components in the community, namely government officials, youth, and the community. Overall, it appears that community involvement as a stakeholder in sister city cooperation in flood mitigation is quite high. The participation of these stakeholders can be used as a form of concern for the development and better progress of the city. Also, Government Performance is a significant contribution that can help in the achievement of the goal of improving people to people diplomacy relations. It can be seen that the internationalisation of the Samarinda flooding problem can create interaction relations between state and non-state actors. The role of the state no longer dominates the patterns of interaction of international cooperation that are developing now, but the smallest state actors such as the people (citizen diplomacy) and city government

\section{Conclusion}

Disasters can be caused by nature (natural disasters) or because of human activities (complex emergencies). Problems that will arise related to how to deal with disasters, especially efforts to resolve and minimize disasters decreased by establishing sister city overseas cooperation. The city government may not be able to respond to all aspects of disaster recovery efforts if it does not coordinate well with various parties. Disaster recovery efforts are carried out by the government if assisted by the community will undoubtedly get optimal results. Therefore, research on the sister city bottom-up cooperation model with community involvement is a compelling new way to solve the flood problem in Samarinda city. The sister city bottom-up cooperation model based on these problems. This cooperation is an effort to involve all parties, especially the community so that every decision taken in planning is a collective decision, and encourages joint involvement and commitment to implement it. Although there are some weaknesses in this model, especially it requires a lot of time and energy in planning, but hopefully, the results can be more effective in flood management.

\footnotetext{
${ }^{31}$ Hayden, Marinao; Fourne, Sebastian; Koene, Bastiaan; Werkman, Renate; and Ansari, Shahzad: "Rethinking 'Top-Down' and 'Bottom-Up' Roles of Top and Middle Managers in Organizational Change: Implications for Employee Support”, Journal of Management Studies, Vol. 54, nº 7 (December 2016), pp. 962-969.
} 
Basically, the stakeholders and the community must be equally pro-active and collaborate in disaster prevention. Each element has its role in the disaster management system. The bottomup model means a strategy or policy that is initiated and carried out by the community. Although it cannot be released also the role of the government. The community has a very vital role in disaster prevention. Because they are the ones, who know in detail the conditions and properties of the surrounding entities, it is hoped that through this system, innovations will be based on local wisdom in disaster management, which can be proposed and run with the government. The government must refer to the hazard map or disaster risk map. So that mitigation and increased preparedness will be right on target. Through this collaborative coordination system, if carried out responsibly and have a sense of mutual need, harmony will be created in managing disasters.

The core of the success of this collaboration is the responsibility, decisions, and real action when a disaster occurs and how the evacuation is carried out. All of which is jointly borne by the municipality and residents. The executor of this cooperation model lies in the efforts of the city government and its people. The city government acts as a provider in monitoring flood-prone areas and guiding to residents. The city government should also collaborate with volunteers and NGOs assisting in the form of funds and energy to the community. The community also strives always to be trained in preventive efforts in critical situations of disaster to be able to provide the best response when an emergency occurs. Preparedness, resilience and active participation of the community are crucial in dealing with flooding problems. These results can be understood because the community is a part of the disaster victims, so they have a high spirit and motivation to act and try in disaster relief that they face in their area.

The authors are completely mindful of impediments and limitations of the examination approach produced for this article however are simultaneously sure of the need of directing the dialogue in this field. Future studies should be expanded to more extensive Indonesia or Southeast Asia territories so that the findings will be generalizable.

\section{Bibiliography}

Alger, Chadwick: "Searching for Democratic Potential in Emerging Global Governance: What Are the Implications of Regional and Global Involvements of Local Governments?" International Journal of Peace Studies, Vol. 16, $\mathrm{n}^{\circ}$. 2, (Winter 2011), pp 133-159.

Baritono, Rafaella: "Eleanor Roosevelt at the United Nations: "Diplomacy from Below" and the Search for a New Transatlantic Dialogue", European Journal of American studies, Vol. 1, $\mathrm{n}^{\mathrm{o}} .12,(2017)$, pp. 1-21.

Bontenbal, Marike: “The Role of European Local Governments in Development Cooperation: Examples from the Netherlands and Germany", in Hoebink Paul (ed.) (2010) European Development Cooperation: In Between the Local and the Global, Amsterdam, Amsterdam University Press, pp. 1-329.

Bontenbal, Marike: 'Dutch Policy on City-to-City Cooperation for Improved Local Governance in South Africa', paper presented at the 5th International Winelands Conference "Public 
Management and Development: Illusion, Delusion, (April 2015), University of Stellenbosch, South Africa.

Buckley, Patrick Henry; Takahashi, Akio; and Anderson, Amy: “The Role of Sister Cities' Staff Exchanges in Developing "Learning Cities": Exploring Necessary and Sufficient Conditions in Social Capital Development Utilizing Proportional Odds Modeling", Environment Res Public Health, Vol. 12, no. 12 (June 2015), pp. 1-23.

Fitriah, Hendrini Renola and Rani, Faisyal: "Implementation of Sister City Collaboration: Sister City Bandung-Braunschweig Case Study in 2000 - 2013 (Implementasi Kerjasama Sister City: Studi Kasus Sister City Bandung-Braunschweig Tahun 2000 - 2013)", Transnasional, Vol. 1, $n^{\circ} .5$, (July 2013), pp. 931-944.

Gusti: “UGM Experts Give Feedback to Overcome Jakarta Floods (Pakar UGM Beri Masukan Mengatasi Banjir Jakarta), Universitas Gadjah Mada Online Publication, (23 January 2013), at https://ugm.ac.id/id/berita/4858-pakar.ugm.beri.masukan.mengatasi.banjir.jakarta.

Hayden, Marinao, et al.: "Rethinking 'Top-Down' and 'Bottom-Up' Roles of Top and Middle Managers in Organizational Change: Implications for Employee Support", Journal of Management Studies, Vol. 54, nº 7 (December 2016), pp. 961-985.

Jovita, Hazel D., Nurmandi, Achmad., Mutiarin, Dyah and Purnomo, Eko P.: "Why does network governance fail in managing post-disaster conditions in the Philippines?" Jàmbá: Journal of Disaster Risk Studies, Vol.10, nº 1 (2018).

Mukti, Takdir Ali (2013). Paradiplomasi: Cooperation by Regional Government In Indonesia (Paradiplomasi: Kerja Sama Oleh Pemda Di Indonesia), Yogyakarta, The Phinisi Press, pp. 1360.

National Disaster Management Authority. "SCDF Committed to Establishing Disaster Management Cooperation (SCDF Berkomitmen Jalin Kerjasama Penanggulangan Bencana)", Badan Nasional Penanggulangan Bencana Online Article. (27 February 2017), at https://bnpb.go.id/scdf-berkomitmen-jalin-kerjasama-penanggulangan-bencana.

Nye, Joseph and Keohane, Robert: "Transnational Relations and World Politics: An Introduction”, International Organization, Vol. 25, nº 3 (Summer 1971), pp. 329-349.

Odoh, Nwogbaga and David: "Reflection on the Theory and Practice of Citizen Diplomacy in the Conduct of Nigeria's Foreign Policy", IOSR Journal Of Humanities And Social Science, Vol. 19, $\mathrm{n}^{\mathrm{o}}$. 10, October 2014, pp. 1-14.

Ogawa, Asuka: "Sister City As A Preservation Strategy", Thesis, Graduate School of Architecture, Planning, and Preservation, Columbia University, 2012, at https://pdfs.semanticscholar.org/ce1b/b7db56d38a516a49b65864a8c69c8e36274c.pdf

Petrenko, Alexander and Schlingloff, Holger: "Eighth Workshop on Model-Based Testing", Proceedings Eighth Workshop on Model-Based Testing, Rome, Italy, (2 March 2013), at https://arxiv.org/abs/1303.0379

Pramono, Sugiarto: "Driving Factors of Cooperation in the Sister Province of Central JavaQueensland (Australia) 1991-2009 (Faktor Pendorong Melakukan Kerjasama Sister Province Jawa Tengah-Queensland (Australia) 1991-2009)", Eksplanasi, Vol. 8 n . 4 (October 2009), pp. 107-119.

Pribadi, Sugeng: "Learn How Japan Fought Floods (Belajar Bagaimana Jepang Mengaatasi Banjir)", Berita Iptek, (April 2007), at http://www.beritaiptek.com/zberita-beritaiptek-200704-04-Belajar-Bagaimana-Jepang-Memerangi-Banjir.shtml 
Rafiq: "Study of Disaster Programs in Flood Disaster Management in Samarinda City at the Regional Disaster Management Agency (BPBD) of East Kalimantan Province" (Studi Tentang Program Kebencanaan Dalam Penanggulangan Bencana Banjir di Kota Samarinda Pada Badan Penanggulangan Bencana Daerah (BPBD) Provinsi Kalimantan Timur)", Administrative Reform Fisip Unmul, Vol. 2, no. 3, 2014, pp. 1548-1560.

Regional Regulation of Samarinda City, Number 6 of 2014.

Samarinda City Government: "History of East Sempaja Village (Sejarah Kelurahan Sempaja Timur). Samarinda City Government Online Publications, (January 2017), at https://kelsempaja-timur.samarindakota.go.id/pages/sejarah-QDEUJ.

Samarinda City Government: "History of Temindung Permai Village (Sejarah Kelurahan Temindung Permai), Samarinda City Government Online Publications, (January 2017), at https://kel-temindung-permai.samarindakota.go.id/pages/sejarah-UMCS.

Shah, Anwar et al: "Empowering States and Provinces or Unshackling Local Governments: Does It Matter for Peace, Order, Good Government, and Growth", The Pakistan Development Review, Vol. 49, $\mathrm{n}^{\circ} .4$ Papers and Proceedings Parts I and II The 26th Annual General Meeting and Conference of the Pakistan Society of Development Economists Islamabad (December 2010), pp. 335-375.

Sunarko, Bagus Sigit and Yuniati, Sri: "Sister City Collaboration: An Effort to Improve the Tourism Industry in Banyuwangi (Kerjasama Sister City: Sebuah Upaya Untuk Meningkatkan Industri Pariwisata Di Banyuwangi)", Repository, Fakultas Ilmu Sosial dan Politik, Universitas Jember, (2016), pp. 1-12, at

http://repository.unej.ac.id/bitstream/handle/123456789/79341/221-234_1.pdf?sequence=2

Tachjan (2006): Public Policy Implementation (Implementasi Kebijakan Publik). Bandung, AIPI.

Weibleder, Stephan and Lackner, Hartmut: "Top-Down and Bottom-Up Approach for ModelBased Testing of Product Lines”, Arxiv, (August 2019), at https://arxiv.org/pdf/1303.1011.pdf.

$\mathrm{Yu}$, Jianxing et al: "Rediscovering Intergovernmental Relations at the Local Level: The Devolution to Township Governments in Zhejiang Province", China Review, Vol. 16, n ${ }^{\circ} .2$, (June 2016), pp. 1-26.

Zhou, Xueguang: "The Institutional Logic of Collusion among Local Governments in China", Modern China, Vol. 36, n. 1, (January 2010), pp. 47-48. 